\title{
MODIFICATION OF THE STRUCTURALLY THE PHASE STATE OF ALUMINUM ALLOY AS A RESULT OF RADIATION THERMAL TREATMENT
}

\author{
E.M. Prokhorenko', V.V. Lytvynenko', V.V. Bryukhovetskiy' ${ }^{1}$ N.A. Shul'gin ${ }^{2}$, I.V. Kolodiy', \\ I.G. Tantsyura ${ }^{2}$, T.G. Prokhorenko \\ ${ }^{1}$ Institute of Electrophysics and Radiation Technologies, Kharkiv, Ukraine; \\ ${ }^{2}$ NSC “Kharkov Institute of Physics and Technology", Kharkiv, Ukraine; \\ ${ }^{3}$ Kharkiv National Automobile and Highway University, Kharkiv, Ukraine \\ E-mail:forshad58@gmail.com
}

The effect of relativistic electron beams on the change in the structure of the 2014 aluminum alloy was studied. The mechanical characteristics (hardness, ultimate strength, conditional yield stress) of the samples were measured before and after irradiation. The influence of phase changes on these mechanical characteristics was investigated. The possibility of cleaning the surface of alloy 2014 using electron beams was studied. The identification of phase inclusions in the aluminum alloy was carried out. The changes in the number of phases that occurred as a result of irradiation with relativistic electron beams were determined.

\section{INTRODUCTION}

Multicomponent aluminum alloys are widely used in the electrical industry, power generation industry, automotive and aviation industries. Aluminum alloys have a number of essential properties. They satisfy a significant number of specific requirements. Alloys have high electrical conductivity, high thermal conductivity. The alloys have low erosion characteristics, wear poorly, and have a high melting point (arc resistance).

For aluminum alloys, technological standards for the production of necessary products have been developed and are used. They are processed by simple methods Also, the advantages of aluminum alloys include the following parameters: low cost of raw materials, low cost of his processing. Due to the high thermal conductivity of aluminum and its alloys, they are widely used as radiators for cooling electrical products. Also, aluminum alloy products have a low weight $(50 \%$ by weight of copper). It should be noted that the strengthto-weight ratio of aluminum alloys is $2-2.8$ times higher than that of steel for all types of alloys.

This is also important in the electrical industry. Due to low force of pressing on and low hardness it is succeeded to get a contact with the maximal degree of connection. The strength of aluminum alloys is higher than at a of pure aluminum. Unlike pure aluminum, multicomponent aluminum alloys are corrosion-resistant in gas environments, and they are not covered with high-resistance films.

Therefore there is possibility to make the wares of different form. All this allows a very widespread use of aluminum alloys in the power industry (especially nuclear), electrical engineer, in production.

Along with a large number of advantages, aluminum and aluminum alloys have a number of properties that reduce the efficiency of their use. At presence of in the environment of moisture and when exposed to stress, high corrosive properties are manifested. This occurs in the area of contacts of aluminum with copper, tungsten, molybdenum. In an atmospheric environment, a highresistance film forms on the surface of aluminum. The hardness of this film is increased.

During the operation of equipment, devices, electrical structures, breakdowns occur. Thus, the origin of emergency situations is possible. Consequently, it is necessary to search the ways of increase of operating descriptions. For this, various technological methods are used.

One of the promising ways to change the properties of materials is their irradiation with ionizing radiation [1-5]. As ionizing radiation, gamma radiation, X-rays, beams of charged particles can be used.

Since products made of aluminum alloys are widely used in nuclear power engineering, then they are exposed to ionizing radiation. Therefore, it is also necessary to study changes in the structural-phase state of aluminum alloys during irradiation.

One of the results of irradiation can be the removal of various parasitic phases from aluminum alloys [6-8]. Under intense action of a beam of accelerated electrons, the temperature of the samples increases. In this case, the surface of the sample is melted or melted. As a result, a change in the phase composition is possible $[9,10]$. This allows you to delete phases with impurities that diminish the purity of the alloy. The evaporation of low-temperature additives also occurs [6,8,10,11]. Evaporation process, improves the purity of materials.

Purpose of work - study of macroscopic characteristics of samples of aluminum alloys 2014. Comparison of the structure of these alloys before and after irradiation with a beam of accelerated electrons. Increase of cleanness of surface of alloys. Determination of mechanisms of changes which happened with macroscopic characteristics of material of samples. 


\section{THE MAIN PART}

In this work, we studied the changes in the properties of the 2014 alloy, which occurred as a result of irradiation with a beam of accelerated electrons. Alloy 2014 has a strength and rigidity in 10 times more than pure aluminum.

This alloy has good forgings descriptions. He has a considerable inoxidizability, possesses high descriptions of durability. Alloy 2014 characterized by the large anisotropy of mechanical properties. It allows to use him as construction material.

The use of alloys as structural materials can lead to situations where products are exposed to areas with various types of ionizing radiation.

Various parts and products are made from alloy 2014. These products are widely used in nuclear power, in the creation of storage facilities for radioactive waste [12]. So, alloy 2014 widely used for making of centrifuges for enriching of uranium. Also, alloy 2014 is used in the manufacture of radiation-protective composite materials [13-16]. It is a matrix element of a polymer metal composite. Also, the alloy, and materials based on it, can be used to protect electronic equipment from the action of electromagnetic pulses and ionizing radiation.

Therefore, it is necessary to know the structural features of the grain structure of the alloy, its evolution. All this makes it possible to understand the processes that will occur in the alloy when it is irradiated with ionizing radiation. One of the types of ionizing radiation are beams of accelerated electrons

When industrial aluminum alloys are irradiated with electron beams, their characteristics change. The main requirement for aluminum alloys is their high radiation resistance. Those the alloy must maintain, within specified intervals, the dimensions, structure and properties under irradiation.

The evaluation of irradiated materials is based on the minimum growth of different violations. In this case, it is necessary to ensure the reliability of the alloy and a sufficient time of his functioning.

When the irradiated material is exposed to fast particles or ionizing radiation, the radiation effect is carried out on the atoms. Atomic-level reactions initiate pore growth. Dislocation loops also appear and grow. The second phase is highlighted. These changes are changes at microscopic level.

These micro structural processes determine the appearance and development of macro effects. These are the effects: hardening; high and low temperature radiation embrittlement; radiation growth; radiation creep; radiation swelling; induced activity. It is necessary to solve the problems of forecasting the development of disturbed areas. It is necessary to determine the general patterns of changes in the structure and physical and mechanical characteristics of alloys. To solve these problems, it is necessary to study the issues of the origin of various violations and defects. For the decision of these tasks it is needed to study the questions of origin of different violations and defects. In this case, it is necessary to trace the dynamics of the development and transformation of these defects.
In [10], the modes of irradiation of aluminum alloys under premelting conditions with the appearance of sections of the liquid phase were found. In this case, finely dispersed crystallites appeared in the alloy material, which increased its surface hardness. At certain radiation doses, it is possible to change the plastic characteristics of aluminum alloys. An increase in the relative elongation to fracture of alloy samples, which are deformed in the superplasticity mode, is found. Alloy 2014 contains $\mathrm{Mg}-\mathrm{Cu}-\mathrm{Si}$.

The chemical composition of the alloy is given in Table 1.

Table 1

Chemical composition of the alloy 2014

\begin{tabular}{|c|c|}
\hline Additives & $\%$ \\
\hline $\mathrm{Cu}$ & $3.9 \ldots 4.8$ \\
\hline $\mathrm{Mg}$ & $0.4 \ldots 0.8$ \\
\hline $\mathrm{Mn}$ & $0.4 \ldots 1.2$ \\
\hline $\mathrm{Fe}$ & 0.7 \\
\hline $\mathrm{Si}$ & $0.6 \ldots 1.2$ \\
\hline $\mathrm{Zn}$ & 0.3 \\
\hline $\mathrm{Ti}$ & 0.1 \\
\hline $\mathrm{Ni}$ & 0.1 \\
\hline $\mathrm{Cr}$ & 0.1 \\
\hline $\mathrm{P}$ & 0.03 \\
\hline $\mathrm{S}$ & 0.03 \\
\hline
\end{tabular}

Alloy 2014 formed with additional introduction in the complement of manganese (Mn). The alloy is hardened by heat treatment. In this case, GuinierPreston zones are formed (lamellar zones with a size of $4 \ldots 10 \mathrm{~nm}$ ) [18]. In these zones, there is an anomalously high concentration of the original substance.

Manganese (alloy $\mathrm{Al}_{12} \mathrm{Mn}_{2} \mathrm{Cu}$ ) is present in the form of dispersed particles (phase T). Due to the presence of the phase of the $\mathrm{Al}_{12} \mathrm{Mn}_{2} \mathrm{Cu}$ alloy, the recrystallization temperature rises and the mechanical properties are improved. Iron is found as an impurity. Presence of iron worsens strength and plasticity. It has the form of plates with the composition $(\mathrm{MnFe}) \mathrm{Al}_{6}$.

Also, an aluminum-insoluble $\mathrm{Al}_{2} \mathrm{Cu}_{2} \mathrm{Fe}$ alloy is formed, which binds copper. Therefore, the amount of iron impurities should be no more than $0.7 \%$. Silicon, forms the phases of $\mathrm{Mg}_{2} \mathrm{Si}$ and $\mathrm{W}\left(\mathrm{Al}_{\mathrm{x}} \mathrm{Mg}_{5} \mathrm{Cu}_{6} \mathrm{Si}_{4}\right)$ [18]. At the same time, the main hardening phases decrease, which reduce the strength characteristics.

There are phosphorus (P) and sulfur in an alloy (S). In quantitative expression the relation of these alloys is small. However these including are parasite. And even their negligible quantity worsens descriptions of aluminum alloys. The phases of sulfur and phosphorus in $\mathrm{Al}(\mathrm{S})$ and $\mathrm{Al}(\mathrm{P})$ also reduce strength descriptions. Therefore one of tasks of treatment of alloy of 2014 beams of electrons is his cleaning from these parasite phases.

\section{LEADTHROUGH OF RESEARCHES, DISCUSSION OF RESULTS}

Alloy 2014 was processed by beams of accelerated electrons on an LUE-10 accelerator. The basic parameters of the accelerator are given in [19]. In our case, the processing was carried out at the following 
beam values: electron energy $\sim 8.2 \ldots 8.3 \mathrm{MeV}$, beam current $-0.8 \mathrm{~mA}$.

Samples with dimensions of $8 \times 40 \mathrm{~cm}$ were processed. The thickness of the samples was $3 \mathrm{~mm}$. The unirradiated sample was designated by the index $(\mathrm{H})$. The rest of the samples were irradiated with different times (sample No. 4 - $210 \mathrm{~s}$, sample No. 5 - $240 \mathrm{~s}$, sample No. 6 - $290 \mathrm{~s}$ ).

The processing time provided fluences of the order of $1015 \mathrm{el} . / \mathrm{cm}^{2}$. It should be noted that these irradiation fluences are insufficient for the evolutionary accumulation of radiation defects. However, the effect of the temperature factor, as a result of heating the samples to $420 \ldots 500^{\circ} \mathrm{C}$, can lead to the initiation of recrystallization processes, the selection of secondary phases.

At the same time, electron irradiation promotes the intensification of these processes as a result of the activation of the electronic subsystem and the creation of a temperature gradient in the volume of the sample. It is necessary to study the issues of the origin of various structural disorders and defects and to trace the dynamics of their development.

In this case, it is possible to predict the development of general patterns of changes in the structure and physical and mechanical characteristics of alloys during irradiation. During irradiation, the samples were diagnosed by optical and Ir-radiometric methods [20].

The work was carried out in stages. At first technological works were conducted on the choice of necessary material. Then the doses were selected and the methods of irradiation were determined. At the next stage, mechanical tests were carried out, with the help of which the physical and mechanical properties of the material were found. After that, studies of the structure of the material were carried out.

To identify the grain structure, such work was carried out. Because, samples contain $90 \%$ aluminum, the work must be done with great care. We made thin sections of the surface of the samples. Their preparation was carried out according to the following scheme.

Samples of the required dimensions were cut from pieces of 2014 alloy. Both irradiated and non-irradiated samples were considered. After it the mechanical polishing was conducted. At the next stage, mechanical polishing was carried out using diamond pastes of various grain sizes. Polishing of surface was conducted by diamond paste with a grain size of $0.25 / 0$.

The final polishing of the surface was carried out in an aqueous solution. After that, the surface was chemically etched. A $22 \%$ acid reagent was used. It contains $78 \%$ water $\left(\mathrm{H}_{2} \mathrm{O}\right), 17 \%$ nitric acid $\left(\mathrm{HNO}_{3}\right)$, and $5 \%$ hydrofluoric acid (HF)

Measuring of size of grain was executed on the secant method. This makes it possible to obtain a relative measurement error of no more than $10 \%$ at confiding probability 0.95 . When examining the starting alloy, the grain size was found to be $29 \mu \mathrm{m}$. The grains are mostly uneven-grained. There is a $30 \%$ scatter in equiaxiality.

Measurement of grain sizes was also carried out for samples after processing. An increase in grain size is observed. So for sample №6 the grain size was $38 \mu \mathrm{m}$.
In parallel with investigations of the surface structure, measurements of microhardness were also carried out. The microhardness was measured by the Vickers method. Used on a LECO LM700AT microhardness tester, with an applied load of $25 \mathrm{~g}$.

For an unirradiated sample, the microhardness was $135.8 \mathrm{~kg} / \mathrm{mm}^{2}$. The average grain size was $29 \mu \mathrm{m}$. As a result of irradiation, the grain size increased and the microhardness decreased. For sample No. 4 (exposure time $210 \mathrm{~s}$ ), we observe an increase in grain size to $34 \mu \mathrm{m}$ and a decrease in microhardness to a value of $117.9 \mathrm{~kg} / \mathrm{mm}^{2}$.

A further increase in the irradiation time leads to a subsequent decrease in microhardness and an increase in the grain size. The values of grain sizes and microhardness for all samples are given in Table 2.

Table 2

Values of grain sizes and microhardness for samples of alloy 2014

\begin{tabular}{|c|c|c|}
\hline $\begin{array}{c}\text { Sample No. } \\
(\text { exposure time, } \mathrm{s})\end{array}$ & $\begin{array}{c}\text { Middle size } \\
\text { of grain, } \mu \mathrm{m}\end{array}$ & $\begin{array}{c}\text { Microhardness, } \\
\mathrm{kg} / \mathrm{mm}^{2}\end{array}$ \\
\hline $\mathrm{H}$ & 29 & 135.8 \\
\hline $4(210)$ & 34 & 117.9 \\
\hline $5(240)$ & 36 & 115.8 \\
\hline $6(290)$ & 38 & 114.1 \\
\hline
\end{tabular}

Large grains appear, which are surrounded by small grains. This is caused by the process of collective recrystallization. The collective recrystallization process is a spontaneous process. It develops as the temperature rises.

Separate grains of metal are thus increased by absorption of nearby grains. Enlargement of grains results in diminishing of free energy of metal. This process is accompanied by the gradual diminishing of grains and disappearance of one grains and increase other.

From the point of view of thermodynamics, collective recrystallization is based on a decrease in grain-boundary energy. The grain structure is thermodynamically nonequilibrium.

The effects of collective recrystallization are observed in aluminum alloys already at their temperatures higher $210^{\circ} \mathrm{C}$. The temperature of collective recrystallization is determined from the equation [17]:

$$
T_{R e}=\alpha T_{\text {Melt }},
$$

where $T_{R e}-$ is the temperature of collective recrystallization; $\alpha-$ is a coefficient depending on the purity of the metal, and $T_{\text {Melt }}-$ is the melting point. For highly pure metals, it reaches a value of 0.1 . With worsening of purity a coefficient is increased. We obtain similar results when examining samples that were irradiated with a longer exposure time.

As you can see from the Table 2, the change in hardness was significant. It is not possible to obtain such a value of hardness only due to collective recrystallization. Consequently, other mechanisms are also responsible for the increase in hardness. Macro mechanical characteristics were obtained from tests carried out on a tensile testing machine. 
For mechanical tests samples long $35 \mathrm{~mm}$, breadthways $2 \mathrm{~mm}$, and thick $4 \mathrm{~mm}$ were made. The measurements were carried out at a temperature of $300{ }^{\circ} \mathrm{C}$. The fulfillment of these works made it possible to identify several regularities in the rupture.

The location of the rupture depends little on the exposure time. All breaks were located in the central part of the sample. Photographs of ruptures are shown in Fig. 1.

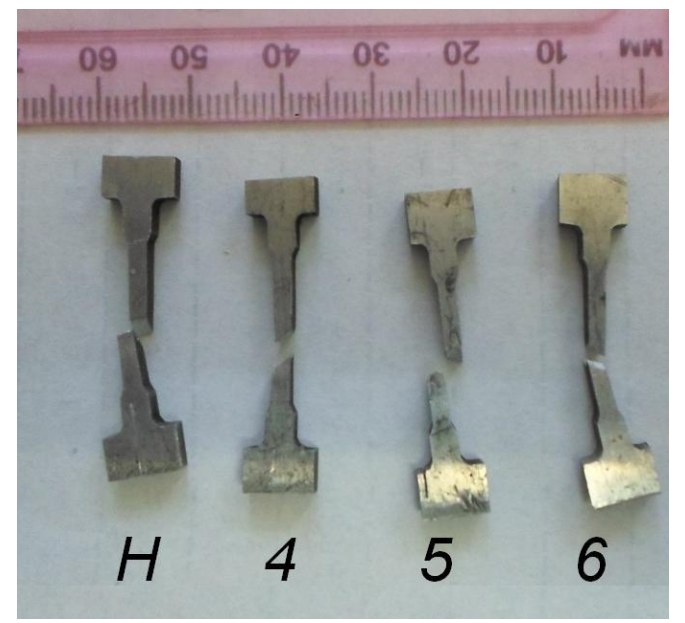

Fig. 1. Different types of sample breaks

All samples have different directions of rupture. The figure shows that the narrowing of the necks of the samples is insignificant. Lengthening of samples absents. According to their characteristics, all the breaks were fragile. This is consistent with the conditions for collective recrystallization.

As a result of the tests carried out, graphs of tensile diagrams were obtained, which are shown in Fig. 2.

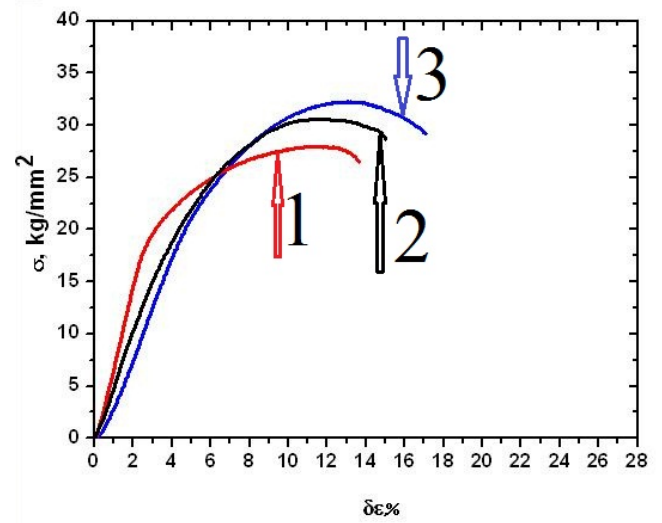

Fig. 2. Graphs of stretch diagrams: 1 - unirradiated sample; 2 -irradiation $210 \mathrm{~s} ; 3$-irradiation $290 \mathrm{~s}$

For all samples in a numerical value, the following were obtained: tensile strength $\left(\sigma_{\mathrm{B}}\right)$, yield stress $\left(\sigma_{02}\right)$. The maximum elongation to failure was obtained. These data are presented in Table 3.

From Fig. 2 and Table 3, we observe that as a result of irradiation, the values of $\sigma_{\mathrm{B}}$ and the values of $\sigma_{02}$ increased.

At the initial stage of stretching, we observe that the values of the applied forces to the irradiated samples are much lower than to the base sample. This indicates the processes of softening in the irradiated samples (at the initial stages of deformation), in comparison with the unirradiated sample. In the course of further deformation, on the contrary, the irradiated samples undergo insignificant hardening.

Table 3

Experimental values of $\sigma_{\mathrm{B}}, \sigma_{02}$, maximum elongation

\begin{tabular}{|c|c|c|c|}
\hline $\begin{array}{c}\text { Sample No. } \\
\text { (exposure } \\
\text { time, } \mathrm{s})\end{array}$ & $\begin{array}{c}\text { Tensile } \\
\text { strength } \\
\sigma_{\mathrm{B}}, \mathrm{kg} / \mathrm{mm}^{2}\end{array}$ & $\begin{array}{c}\text { Yield } \\
\text { stress } \sigma_{02}, \\
\mathrm{~kg} / \mathrm{mm}^{2}\end{array}$ & $\begin{array}{c}\text { Maximum } \\
\text { elongation to } \\
\text { break, } \%\end{array}$ \\
\hline $\mathrm{H}$ & 28 & 20 & 14 \\
\hline $4(210)$ & 30 & 23 & 15 \\
\hline $5(240)$ & 31 & 24 & 16 \\
\hline $6(290)$ & 33 & 27 & 17 \\
\hline
\end{tabular}

The structure of the surface layer of the aluminum alloy was investigated using optical microscopes MIM-6, MBS-9, BRESSER-NV-1200.

A photograph of the surface of an unirradiated sample is shown in Fig. 3.

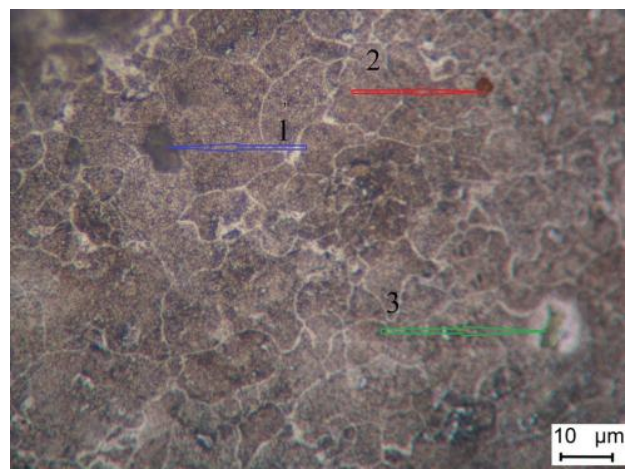

Fig. 3. Microstructure of an unirradiated sample of alloy 2014. Arrows indicate characteristic inclusions

On the surface of the material, inclusions of various alloys were found. Upon detailed examination of the images, it was found that the inclusions indicated by the arrow 1 (blue) is a $(\mathrm{MnFe}) \mathrm{Al}_{6}$ plate $[21,22] . \mathrm{Al}_{2} \mathrm{Cu}_{2} \mathrm{Fe}$ alloy inclusions were also found (arrow 2, red).

Aluminosilicate inclusions were also found, which form the $\mathrm{W}\left(\mathrm{Al}_{\mathrm{x}} \mathrm{Mg}_{5} \mathrm{Cu}_{6} \mathrm{Si}_{4}\right)$ phases [21, 22]. In the figure, they are indicated by a green arrow with number 3. Some aluminosilicate alloys are located in the intergranular space. Various phases $\mathrm{Al}_{2} \mathrm{Cu}, \mathrm{Al}_{3} \mathrm{Mg}_{2}$, $\mathrm{Mg}_{2} \mathrm{Si}, \mathrm{Al}_{2} \mathrm{CuMg}$ were also identified.

Some of the phases $\left(\mathrm{Al}_{2} \mathrm{Cu}, \mathrm{Al}_{3} \mathrm{Mg}_{2}\right)$ form binary eutectic phase diagrams with the aluminum-based solid solution. These phases are present in insignificant amounts. However, they strongly influence the properties of aluminum alloys. The $\mathrm{Mg}_{2} \mathrm{Si}$ alloy strongly affects the hardness. The hardness of individual inclusions of the $\mathrm{Mg}_{2} \mathrm{Si}$ alloy is $400 \ldots 430 \mathrm{~kg} / \mathrm{mm}^{2}$.

We also studied images of the surface of the samples that were irradiated. The time of exposure to the beam was different. For example, we will give a photograph of the surface of sample No. 6 (irradiation time $290 \mathrm{~s}$ ).

Arrows mark typical inclusions (Fig. 4). In the photograph of the surface, inclusions similar to those in the unirradiated sample were found. So arrows 1 (blue) indicate $(\mathrm{MnFe}) \mathrm{Al}_{6}$.

Inclusions of the $\mathrm{Al}_{2} \mathrm{Cu}_{2} \mathrm{Fe}$ alloy were also found. These alloy do not leave when the aluminum alloy is irradiated with a beam of accelerated electrons. Their 
transformation requires large values of energies and absorbed doses.

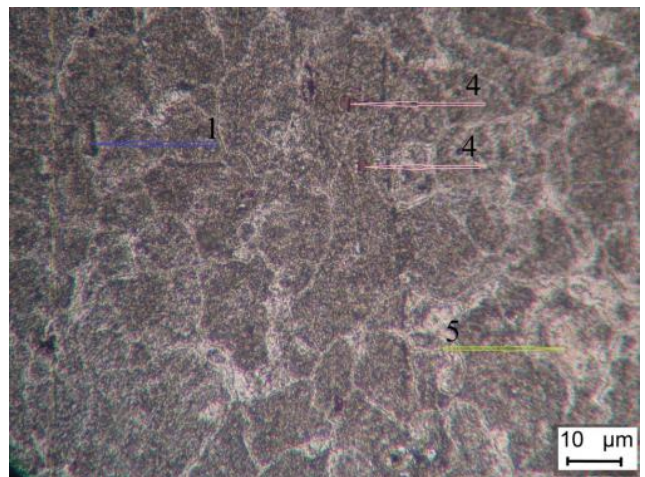

Fig. 4. Microstructure of irradiated sample No. 6 (irradiation time $290 \mathrm{~s}$ )

Arrow 4 (pink) denotes the inclusions of the $\mathrm{Mn}_{3} \mathrm{Al}_{2}$ alloy. These inclusions are reinforcing. Arrow 5 (yellow) indicates $\mathrm{Mg}_{2} \mathrm{Si}$ silicates. Based on X-ray structural analysis, it was found that the amount of $\mathrm{Mn}_{3} \mathrm{Al}_{2}$ and $\mathrm{Mg}_{2} \mathrm{Si}$ alloys decreased after irradiation.

Consequently, as a result of irradiation with accelerated electrons of the samples, the $\mathrm{Mn}_{3} \mathrm{Al}_{2}$ and $\mathrm{Mg}_{2} \mathrm{Si}$ alloys dissolve. X-ray diffraction analysis of the samples that were irradiated with a different exposure time also revealed a decrease in the inclusions of the $\mathrm{Mn}_{3} \mathrm{Al}_{2}$ and $\mathrm{Mg}_{2} \mathrm{Si}$ alloys. Their number is directly proportional to the time of exposure to the beam. The minimum amount of inclusion of alloys $\mathrm{Mn}_{3} \mathrm{Al}_{2}$ and $\mathrm{Mg}_{2} \mathrm{Si}$ is found in a sample No 6. This is the sample with the maximum exposure time. Therefore, the main reason for the decrease in the hardness of the aluminum alloy is the decrease in the inclusions of $\mathrm{Mn}_{3} \mathrm{Al}_{2}$ and $\mathrm{Mg}_{2} \mathrm{Si}$.

When examining the samples, the presence of $\mathrm{Al}(\mathrm{S})$ and $\mathrm{Al}(\mathrm{P})$ inclusions was investigated. X-ray structural analysis showed that after irradiation the number of $\mathrm{Al}(\mathrm{S})$ and $\mathrm{Al}(\mathrm{P})$ inclusions decreased.

The number of these inclusions is minimal in the sample with the maximum exposure time (No. 6). Thus, as a result of processing the samples with a beam of accelerated electrons, the surface of the material that was exposed to irradiation is cleaned.

At the next stage, we analyzed the fracture surface of the samples. An image of the samples is given in Fig. 1. Investigations were carried out using a scanning electron microscope JEOL JSM 840. An image of the fracture surface is shown in Fig. 5

From the photo Fig. 5,a (unirradiated sample $(\mathrm{H})$ ) it follows that the rupture took place at two different heights. The gap occurred from bottom to top. In the center of the specimen there is a material with increased strength, which is a stop for the growth of the rupture. Further movement of the gap was on a higher platform.

In Fig. 5,b (sample after irradiation No.6), we observe a slightly different pattern of rupture. The rupture had several rupture directions. They all went from areas of lower strength to areas of higher strength. Areas on the outskirts of the sample were less durable. An area in a center is interesting for the presence of several zones with different durability. For a more detailed analysis of the fracture surface of the sample, a higher image resolution was used.
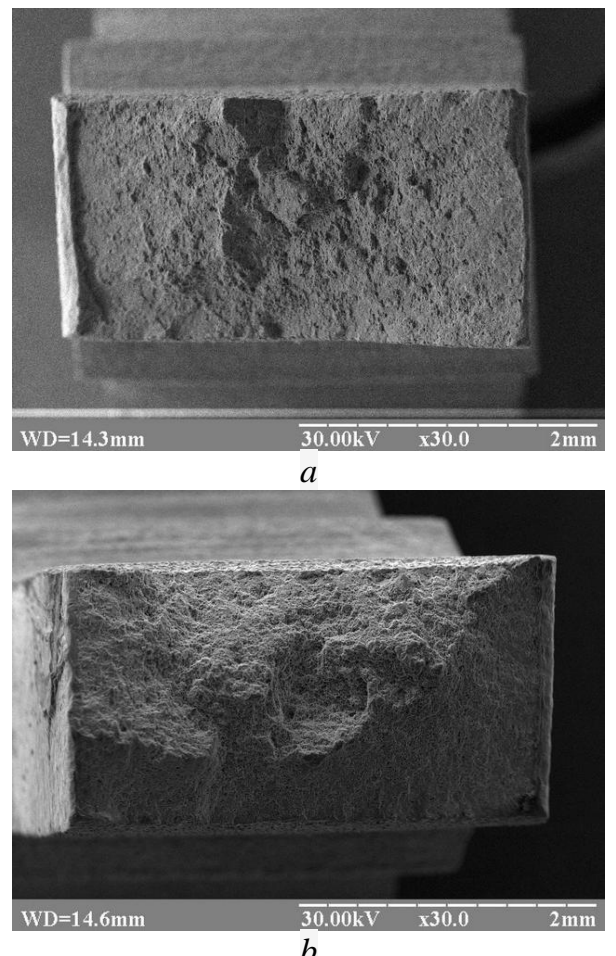

$b$

Fig. 5. The structure of ruptures of samples: a-before irradiation (sample No. H); $b$-after irradiation (sample No. 6). Magnification $\times 30$

In Fig. 6 shows photographs of the same samples as in Fig. 5, but with a higher magnification. They also show identified inclusions and structural features.
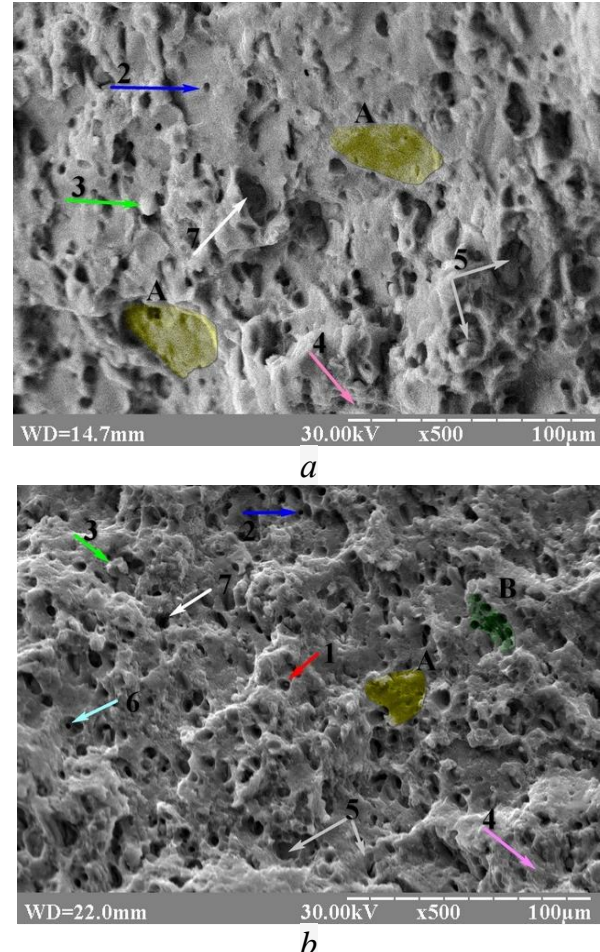

Fig. 6. The structure of ruptures of samples with the noted features: $a$-before irradiation (sample No. $H$ ); $b$-after irradiation (sample No. 6) Magnification $\times 500$. 
As the resolution is increased, it becomes possible to obtain additional information on the sample rupture. On the discontinuity surface, we observe the local existence of various kink mechanisms. This is due to a wide range of alloy components, the presence of several types of phases in the alloy, and so on [21, 22].

In Fig. 6,a we observe the structure of a brittle rupture of an unirradiated sample. The field of the microscope got the area that in Fig. 4, is on the right (flat discontinuity region). The predominant structure of rupture is intergranular rupture. In the lower part of the image, the craters have elongated walls. This indicates the presence of a viscid rupture in this region. Points along the surface of grains are determined by the presence of various impurities in the alloy. Based on the specific characteristics of the rupture, we determine the types and composition of microinclusions [21, 22].

In Fig. 6,b shows an image of the fracture surface of a sample made of irradiated alloy 2014 (sample No. 6). Identification of defects found on the fracture surface was performed.

On the surface of the grains (see Fig. 6), we observe a significant number of craters and funnels with elongated walls. They were formed at the points where various inclusions, intermetallic compounds are located. Several mechanisms work at break. The main area was occupied by intergranular brittle rupture. Its approximate sample is marked in yellow (index A). It has a flat surface with few pits of various types. Second, in terms of the occupied area, there is a fragile gap that runs along the subboundary (green, index B). On its surface there are several small equiaxed pits with normal boundaries. Their number is much higher than in other points. One of the reasons for their increased concentration on the surface of grains may be the peculiarities of the passage of collective recrystallization in aluminum alloys [17, 21, 22].

During the radiation treatment of the alloy, mobile grain boundaries are formed. In microscopic examination, a process of increasing the mobility of dislocations is observed, and the processes of migration of vacancies are intensified. In this case, subgrains are formed (crystallites with small differences in orientation, less than $10^{\circ}$ ) and the walls of individual crystals are transformed into pseudo flat subboundaries. Pseudo flat (subboundary) subboundaries are crystal walls of high curvature and increased mobility. These walls are formed by flat pile-ups of dislocations. In this case, various impurities, intermetallic particles and inclusions move at the front of the subboundary. This contributes to an increase in their concentration at the border. With an increase in various inclusions, the adhesion force of individual particles with the alloy matrix also changes. This increases the number of craters on the rupture surface.

Various inclusions were found in the material of the sample. So the red arrow (index one) denotes the pits in which the iron-rich inclusion is located. An insignificant number of pits, which are similar to this one, are located on the fracture surface. This iron containing inclusion is the $\mathrm{Al}_{2} \mathrm{Cu}_{2} \mathrm{Fe}$ alloy, which does not dissolve in the 2014 alloy.
This alloy was found on the surface of the samples (see Fig. 3 (red pointer 2)). Pits are formed around this inclusion. They are symmetrical and have straight top edges. The pits have a characteristic shape and structure (tongue shaped core). Therefore, the detection of such pits makes it possible to determine the structure of the alloy.

A blue pointer (index 2) marks the characteristic pits. They have a deep of $3 \ldots 5 \mu \mathrm{m}$. The pits are in the shape of a regular circle. The pits are located over the entire surface of the rupture and have arisen in the places where micropores are concentrated. Micropores arise in the area of concentration of various violations of the material matrix. Micropores and microcracks can be one of the types of imperfections. Under conditions of three-dimensional volumetric force required to rupture the of border of the material matrix, micropores accumulate and micropores slide to separate areas. During this process, micropores grow and confluence of micropores. Subsequently, a rupture occurs with the formation of pits. The shape and depth of the pits depends on the fracture pattern, the type of fracture (fragile or viscid) and the from purity of the material matrix

Arrow 3 (green) denotes the phases of aluminosilicates W (AlxMg5Cu6Si4). Aluminosilicates of this type have significant hardness, but are weakly bound to the alloy matrix. When they break, they come off in a whole lump. Their presence reduces the strength and plasticity of our alloy.

A pink arrow (see index 4, Fig. 6) marks a fragile spall. The spall has the structure of a brook and spread vertically into the depth of the sample. Spalls appear in the case of nonuniform motion of the fracture surface.

In our case, the gap moved from bottom to top in the picture. The cleavage is at the bottom. Consequently, at the initial part of the rupture, it passed as a cleavage.

In Fig. 6,a and we observe only one cleavage area. After irradiation, there are already three of them (see Fig. 6,b). Thus, as the dose is increased, the fragility may increase. This statement is in good agreement with the fact that an increase in grains occurs as a result of collective recrystallization.

Intragrain breaks are marked with a gray arrow (marker 5). In these points, $(\mathrm{MnFe}) \mathrm{Al}_{6}$, inclusions are concentrated, which have a lower hardness and can fracture under tension.

Arrows 6 and 7 denote fossulas, which have a regular shape and significant size. Their diameter is $8 \mu \mathrm{m}$, the depth is $5 \ldots 8 \mu \mathrm{m}$. These fossulas were formed in the area of inclusions based on manganese $\left(\mathrm{Mn}_{3} \mathrm{Al}_{2}\right)$ [10, 11]. Apparently, the region with the addition of $\left(\mathrm{Mn}_{3} \mathrm{Al}_{2}\right)$ remains attached to the main matrix, and the edges of alloy stretch.

Since manganese is an alloying addition, the increased number of such pits indicates an increased strength in this area. At the point marked with arrow 6, there is a small spherical fossa at the bottom of the large fossa. The basis of its formation was the increase in micropores.

In addition, the cause of the formation of craters may be the pulling of grains in the process of lead 
through of break works. In this case, equiaxed rounded funnels are formed.

Thus, as a result of the affecting of a beam of accelerated electrons on the 2014 alloy, there is a change of his structure.

\section{CONCLUSIONS}

1. As a result of the action of a beam of accelerated electrons, the structure of the 2014 aluminum alloy changed.

2. It was found that as a result of irradiation, there is a decrease in parasitic inclusions that contain phosphorus and sulfur. The cleanness of surface of aluminum alloy became better thus.

3. It is found that the hardness of aluminum alloys decreases with increasing of time of irradiation

4. Tensile strength, limit of fluidity, maximum elongation to fracture were measured. These characteristics increase with increasing exposure time.

5. It was determined that the accumulation of microinclusions at the subboundary occurs as a result of collective recrystallization.

6. On the basis of the specific characteristics of the alloy, the types and composition of microinclusions were determined.

\section{REFERENCES}

1. C. Dong et al. Surface treatment by high current pulsed electron beam // Surface and Coatings Technology. 2003, v. 163-164, p. 620-624.

2. E.M. Prokhorenko, V.V. Lytvynenko, O.A. Melyakova, Yu.F. Lonin, A.G. Ponomarev, V.T. Uvarov, N.A. Shul'gin, T.G. Prokhorenko, R.I. Starovoytov, A.I. Morozov, S.R. Artemev. Strengthening of the surface of steel (9ХФМ) exposed to a high-current electron beam // Problems of Atomic Science and Technology. 2020, N 1(125), p. 167-172.

3. Y. Geng, I. Panchenko, S. Konovalov, et al. Effect of electron beam energy densities on the surface morphology and tensile property of additively manufactured Al-Mg alloy // Nuclear Inst. and Methods in Physics Research, B. 2021, v. 498, p. 15-22.

4. E.M. Prokhorenko, V.V. Lytvynenko, O.A. Melyakova, Yu.F. Lonin, A.G. Ponomarev, V.T. Uvarov, N.A. Shul'gin, T.G. Prokhorenko. Modification of structure of the surface of steel (ХГC) as result of influences of high-current electron beem // Problems of Atomic Science and Technology. 2020, N 2(126), p. $47-$ 53.

5. V.V. Bryukhovetsky et al. The features of the structural state and phase composition of the surface layer of aluminum alloy $\mathrm{Al}-\mathrm{Mg}-\mathrm{Cu}-\mathrm{Zn}-\mathrm{Zr}$ irradiated by the high current electron beam // Nuclear Inst. and Methods in Physics Research B. 2021, v. 499, p. 25-31; https://doi.org/10.1016/j.nimb.2021.02.011.

6. S.Ye. Donets et al. Aluminum surface coating of copper using high-current electron beam // Problems of Atomic Science and Technology. 2015, N 4(98), p. 302305.

7. E.M. Prokhorenko, V.F. Klepikov, V.V. Lytvynenko, P.A. Khaymovich, N.A. Shul'gin, A.I. Morozov. Diagnostics of processes of wear of materials of balls drum mills // Eastern European Journal of Enterprise Technologies. 2015, N 1/5, v. 73, p. 14-20.

8. J.X. Zou, K.M. Zhang, C. Dong, Y. Qin, S.Z. Hao, T. Grosdidier. Selective surface purification via crater eruption under pulsed electron beam irradiation // Applied Physics Letters. 2006, v. 89, issue 4, p. 1904-1913; doi: 10.1063/1.2234306.

9. D. Zaguliaev, Y. Ivanov, S. Konovalov, V. Shlyarov, D. Yakupov, A. Leonov. Effect of pulsed electron beam treatment on microstructure and functional properties of $\mathrm{Al}-5.4 \mathrm{Si}-1.3 \mathrm{Cu}$ alloy // Nuclear Instruments and Methods in Physics Research, Section B. 2021, v. 488, p. 23-29; https: // doi.org /10.1016 /j.nimb.2020.12.004.

10. V.F. Klepikov, E.M. Prokhorenko, V.V. Lytvynenko, A.A. Zaharchenko, M.A. Hazhmuradov. Control of macroscopic characteristics of composite materials for radiation protection // Problems of Atomic Science and Technology. 2015, N 2(96), p. 193-196.

11. Lu Diankun, Gao Bo, Zhu Guanglin, Lv Jike, Hu Liang // High Temp. Mater. Proc. 2017, N 36(1), p. 97-100.

12. V.F. Klepikov, E.M. Prokhorenko, V.V. Lytvynenko, S.E. Donets, V.N. Robuk, T.G. Prokhorenko, V.T. Uvarov, A.G. Ponomarev, Yu.F. Lonin The use of high-current relativistic electron beams for the study of the effects of ionizing radiation on materials storage RAW // Problems of Atomic Science and Technology. 2016, N 2(102), p. 72-77.

13. V.F. Klepikov, E.M. Prokhorenko, V.V. Lytvynenko, A.A. Zaharchenko, M.A. Hazhmuradov. Performance Ratio Hardness Characteristics Polystyrene-Metal Composite Materials // Problems of Atomic Science and Technology. 2015, N 5(99), p. 3642.

14. V.F. Klepikov, E.M. Prokhorenko, V.V. Lytvynenko, A.A. Zaharchenko, M.A. Hazhmuratov. Application of methods of modeling of radiationprotective characteristics of polystyrene-metal composite materials // Problems of Atomic Science and Technology. 2016, N 3(103), p. 123-127.

15. E.M. Prohorenko, V.V. Lytvynenko, A.A. Zaharchenko, M.A. Hazhmuratov, T.G. Prokhorenko. Studying the changes in the characteristics of radiationprotective composition materials in dependence on homogeneity of distributing of metal components // Problems of Atomic Science and Technology. 2019, N 2(120), p. 121-126.

16. E.M. Prokhorenko, V.V. Lytvynenko, A.A. Zakharchenko, M.A. Khazhmuradov, S.A. Sokolov, T.G. Prokhorenko, A.P. Ben. Analysis of radiation protective properties of polystyrene-based composite materials // Problems of Atomic Science and Technology. 2021, № 3(133), p. 111-118; https: //doi.org/10.46813/ 2021-133-111.

17. Yu.M. Lakhtin, V.P. Leontieva. Material Science. M.: "Materials Science", 1990, 528 p.

18. V.V. Bryukhovetskiy, N.I. Bazaleev, V.F. Klepikov, V.V. Litvinenko, O.E. Bryukhovetskay, E.M. Prokhorenko, V.T. Uvarov, A.G. Ponomar'ov. Features of gelation of surface of industrial aluminum alloy 6111 in the area of influence of impulsive bunch of electrons in the mode of premelting // Problems of 
Atomic Science and Technology. 2011, N 2(72), p. 2832.

19. N.I. Ayzatsky, V.N. Boriskin, A.N. Dovbnya, A.I. Zykov, $\quad$ E.S. Zlunitsyn, S.P. Karasev, M.A. Krasnogolovets, V.A. Popenko, G.D. Pugachev, Yu.D. Tour, V.L. Uvarov, G.L. Fursov. Radiation technology with the use of electron and bremsstrahlung // Problems of Atomic Science and Technology (33). 1999, N 1, p. 61-63.

20. E.M. Prohorenko, V.F. Klepikov, V.V. Lytvynenko, N.I. Bazaleyev, I.I. Magda, T.G. Prohorenko,
A.I. Morozov. Application of ir-radiometric diagnostics for control of vacuum connections of electrophysical installations // Problems of Atomic Science and Technology. 2018, N 1(113), p. 212-217.

21. Dzh. Fellouz Fraktography and Atlas of fraktographs. Ohio: "Metals park", 1982, 489 p.

22. Lucio F. Mondolfo. The structure and properties of aluminum alloys. University of Michigan: "Butterworths", 1976, 971 p.

Article received 30.09.2021

\title{
МОДИФИКАЦИЯ СТРУКТУРНО-ФАЗОВОГО СОСТОЯНИЯ АЛЮМИНИЕВОГО СПЛАВА В РЕЗУЛЬТАТЕ РАДИАЦИОННО-ТЕРМИЧЕСКОЙ ОБРАБОТКИ
}

\author{
Е.М. Прохоренко, В.В. Литвиненко, В.В. Брюховецкий, Н.А. Шульгин, И.В. Колодий, \\ И.Г. Танцюра, Т.Г. Прохоренко
}

Изучалось влияние воздействия релятивистских электронных пучков на изменение структуры алюминиевого сплава 2014. Измерялись механические характеристики (твердость, предельная прочность, условный предел текучести) образцов до и после облучения. Исследовалось влияние на эти механические характеристики изменения фаз. Изучалась возможность очистки поверхности сплава 2014 при помощи электронных пучков. Проводилась идентификация включений фаз в алюминиевом сплаве. Определялись изменения в количестве фаз, которые произошли в результате облучения релятивистскими электронными пучками.

\section{МОДИФІКАЦІЯ СТРУКТУРНО-ФАЗОВОГО СТАНУ АЛЮМІНІЕВОГО СПЛАВУ В РЕЗУЛЬТАТІ РАДІАЦІЙНО-ТЕРМІЧНОЇ ОБРОБКИ}

\author{
С.М. Прохоренко, В.В. Литвиненко, В.В. Брюховецький, М.А. Шульгін, І.В. Колодій, \\ І.Г. Танцюра, Т.Г. Прохоренко
}

Вивчався вплив дії релятивістських електронних пучків на зміну структури алюмінієвого сплаву 2014. Вимірювалися механічні характеристики (твердість, гранична міцність, умовна межа текучості) зразків до і після опромінення. Досліджувався вплив на ці механічні характеристики зміни фаз. Вивчалася можливість очищення поверхні сплаву 2014 за допомогою електронних пучків. Проводилася ідентифікація включень фаз в алюмінієвому сплаві. Визначалися зміни в кількості фаз, які сталися в результаті опромінення релятивістськими електронними пучками. 